\title{
Effect of Pretreatments on the Quality of Grape Wine
}

\author{
R. Navarasam*, N. Karpoora Sundara Pandian, B. Dhanalakshmi and M. Abdul Reiyas
}

Food Technology, Tamil Nadu Veterinary and Animal Sciences University, College of food and Dairy Technology, Koduveli, Chennai-600052, Tamil Nadu, India

*Corresponding author

\section{A B S T R A C T}

\section{Keywords}

Red wine, Conventional thermal Pasteurization, Microwave treatment,

Tannin, Catechin

Article Info

Accepted:

04 September 2018

Available Online:

10 October 2018
This research paper concentrated on studies on the effect of pretreatments on the quality of grape wine. The changes due to pretreatments on the functional properties are such as total phenols, tannins and catechins. Hence, various thermal treatments such as microwave with a combination of $300 \mathrm{~W}$ for 2, 4 and 6 min and conventional thermal pasteurization at 50, $60,70^{\circ} \mathrm{C}$ with the time interval of 30 and 60 s were applied to the grape must to study the extraction efficiency of polyphenols. The quality parameters of prepared wine from the grape must subjected to conventional thermal pasteurization at $70^{\circ} \mathrm{C}$ for $60 \mathrm{~s}$ revealed increase in total phenolic compound and tannin content with mean values of 210.43 $\mathrm{mg} / 100 \mathrm{ml}$ of wine and $118.27 \mathrm{mg} / 100 \mathrm{ml}$ of wine, respectively whereas microwave treatment for 6 min revealed increase in catechin content with mean value of $68.95 \mathrm{mg} /$ $100 \mathrm{ml}$ of wine at the end of fermentation.

\section{Introduction}

Pasteurization is a thermal process in which heating of liquid food at particular time and successive cooling is performed with the intention of killing pathogens and deactivating enzymes. Grape juice pasteurization even kills the most resistant mold which is detrimental for the production of quality wine (Pederson, 1936).

Hence, pasteurization of grape must prior to fermentation (the inoculation of yeast) may facilitate the population of yeast in the development of quality wine.

Pasteurization can be accomplished by conventional heating, microwave exposure and high pressure processing (Liu and Casas, 2010). Since high pressure processing is expensive, conventional thermal pasteurization and microwave exposure may be the choice of pretreatment on grape must in preventing mixed culture fermentation and extracting the bioactive compounds from the grapes towards the production of quality grape wine.

The applied pre-treatments will inhibit such kind of problems and maintain the product quality and stability. By introducing the different levels of dosages of pre-treatments like microwave and ultra-violet and blanching, we can perceive the long shelf-life, maintenance of the nutritional content and quality of grape wine. 
By analyzing the impacts of pre-treatments on the quality of grape wine, we can provide scientific knowledge on the quality aspects of fermented beverages to food industries those are undergoing fruit processing and preservation. Grapes contains high amount of phenolic compounds that possess antioxidant property which prevents cancer, it reduces the risk of strokes and also it boosts-up the immune system.

Hence, thermal treatments such as conventional thermal pasteurization and microwave pasteurization on grape must were designed to fulfill the targeted objective.

\section{Materials and Methods}

In this section, materials and methods used in the preparations of grape wine, pretreatments and quality evaluation are discussed.

\section{Materials}

\section{Grapes}

The grapes used in the present study were of good grade local variety, acidic and procured from local market.

\section{Yeast culture}

To ferment the grape must, commercially available dry granular brewers' yeast procured from Venus Essence, Chennai. The culture was stored at $4^{\circ} \mathrm{C}$.

\section{Sugar}

Sucrose was added during the process to adjust the Total Soluble Solids (TSS). The sugar content is expressed as per cent soluble solids or ${ }^{\circ}$ Brix. Initial Sugar content of grape must was measured using a refractometer. The TSS per cent was adjusted to $22^{\circ}$ Brix by adding sugar for effective fermentation.

\section{Chemicals}

The following chemicals were used for the quality analysis of grape must and wine includes standard sodium hydroxide, phenolphthalein, methanol, sodium carbonate, FCR reagent (Folin Ciocalteau Reagent), gallic acid, cuprous sulfate, sodium potassium tartrate, sodium iodide, sulphuric acid, starch, sodium thiosulfate, methylene blue, Fehling A and B solutions, glucose, lead acetate, potassium chromate.

\section{Glassware}

Glass wares viz., burette, pipette, volumetric flask, conical flask, measuring cylinder, test tubes, beaker, petri plates, desiccators, weighing balance, round bottom flask, digestion flask and sterilized jars were used for experimentation.

\section{List of devices or instruments used in experimentation}

Magnetic stirrer (Make: Remi equipments), pH meter (Make: SUSIMA Technologies Private Limited, Chennai), Distillation flask, Pycnometer, Hydrometer, Thermometer, Hot plate, Microwave oven (make: Godrej), UVVisible spectrophotometer (Make: UV mini 1240 shimadzo), Distillation unit (Borosil).

\section{Methods}

\section{Selection of fruits}

Undamaged, healthy ripened grapes having average $\mathrm{pH}$ of 3.0 to 3.6 were selected after manual sorting and discarding of defective bunches.

\section{Preparation of grape must}

Undamaged, $20 \mathrm{~kg}$ of healthy ripened grape berries were de-stemmed and then washed 
with boiled and cooled water. With the help of fruit juicer (available at the department of Food Plant Operation, CFDT) grape must was prepared. Grape skins and seeds were kept in must itself for extraction of color and phenolic compounds. The must was kept overnight under aerobic fermentation.

\section{Analysis of grape must}

The grape must was analyzed to estimate the sugar level, $\mathrm{pH}$ and amount of phenolic compounds.

\section{Preparation of sugar solution}

Commercial sugar was procured from the local market. The stock sugar solution was prepared by dissolving $50 \mathrm{~g}$ of sugar in $50 \mathrm{ml}$ of water boiled for 10 minutes and then allowed to cool at room temperature and used for supplementation in grape must to adjust the sugar level to $22{ }^{\circ}$ Brix by using hand refractometer.

\section{Pre-fermentation treatments}

The extracted grape must was subjected to pretreatments before its fermentation by the yeast to produce ethanol. The grape must was subjected to thermal treatments with conventional pasteurization and microwave radiation to destroy the pathogens (Table 1).

It could help to improve the color intensity and phenolic contents in the final product.

\section{Pasteurization}

Pasteurization is the effective heat treatment to destroy all pathogenic organisms which causes spoilage to the product. The temperature is a variable that directly affects the growth rate of the microorganisms (Charoenchai et al., 1998) and the final composition of wine (Torija et al., 2003). Hence, the grape must was subjected to thermal exposure at 50,60 and $70^{\circ} \mathrm{C}$ for 30 and $60 \mathrm{~s}$, respectively (Plate 2.2).

\section{Microwave treatment}

The prepared grape must was subjected to radiative treatments under microwave exposure (Plate 2.3) at a power level of $300 \mathrm{~W}$ with time intervals of 2,4 and 6 minutes before addition of starter culture to destroy the harmful microorganisms and extract bioactive compounds from grape skin and seeds in the must.

\section{Preparation of starter culture}

The starter culture was prepared by using $2 \%$ of brewer's yeast. It was activated by adding $2 \mathrm{~g}$ of yeast into $100 \mathrm{ml}$ of warm water. Activation of yeast was observed by rise in the volume of yeast in warm water.

\section{Alcoholic fermentation of grape must}

The pretreated grape must $(500 \mathrm{ml})$ was taken in $1000 \mathrm{ml}$ Erlenmeyer flask and added with sugar syrup (given in 2.2.4) to adjust the sugar level at $22^{\circ}$ Brix. The prepared must was inoculated with $2 \%$ starter culture and incubated at $28^{\circ} \mathrm{C}$. Steps involved in the alcoholic fermentation are presented in figure 1.

\section{Post fermentation process}

The finished wine contains impurities including dead cells, protein hazes and residual sugars and does not have complete quality (sensory) attributes. Hence, it requires post fermentative treatments to make wine potable. In fact, there are five goals of "finishing" a wine: clarity, stability, compositional adjustment, style development and packaging. It is also important to prevent unwanted microbial growth in the wine after primary fermentation (i.e., alcoholic 
fermentation) is complete as this will affect the flavor and aroma profile. After alcoholic fermentation, post fermentation processes were carried out.

\section{Siphoning / Racking}

The flasks or bottles containing prepared wines were stored in refrigeration and debris called 'lees' was allowed to settle by gravity. No settling or fining agent was added. The clear supernatant was siphoned and bottled separately.

\section{Bottling and Storage}

The cleared wine was stored in glass bottles (sterile bottles) under refrigerated conditions. The sequential operations followed in grape wine production is given in plate 2.4.

\section{Results and Discussion}

Table 2 shows the total phenol content $(\mathrm{mg} / 100 \mathrm{ml})$ of control and pretreated samples during wine making. Mean values of total phenol content in control and pretreated samples $\quad(452.28 \pm 0.26, \quad 445.58 \pm 0.25$, $449.27 \pm 0.35, \quad 454.88 \pm 0.28, \quad 445.23 \pm 0.2$, $446.03 \pm 0.26, \quad 450.07 \pm 0.23, \quad 450.42 \pm 0.27$, $452.60 \pm 0.34$ and $458.17 \pm 0.22$ ) were obtained during $0^{\text {th }}$ day of wine making. Mean values of total phenol content in control and pretreated samples $\quad(175.12 \pm 0.12, \quad 176.62 \pm 0.17$, $178.98 \pm 0.12, \quad 190.73 \pm 0.22, \quad 176.35 \pm 0.19$, $178.40 \pm 0.17, \quad 182.07 \pm 0.22, \quad 190.77 \pm 0.3$, $195.85 \pm 0.3$ and $210.43 \pm 0.3$ ) were obtained during $20^{\text {th }}$ day.

It was found that there was significant $(\mathrm{P} \leq 0.01)$ difference in the values of total phenol content of control and pretreated samples during wine making. There were significant changes $(\mathrm{P} \leq 0.01)$ in the total contents in the treatments during the successive intervals of wine making.
Table 3 shows the tannin content $(\mathrm{mg} / 100 \mathrm{ml})$ of control and pretreated wine samples. Mean values of the tannin content $(\mathrm{mg} / 100 \mathrm{ml})$ in control and pretreated wine samples

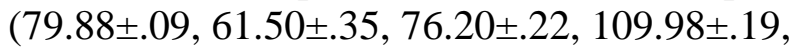
$86.18 \pm .26,94.83 \pm .12,95.05 \pm .23,105.70 \pm .12$, $100.20 \pm .12$ and $118.27 \pm .17)$ were obtained. It was found that there was significant difference $(\mathrm{P} \leq 0.01)$ in the values of the tannin content $(\mathrm{mg} / 100 \mathrm{ml})$ of pretreated wine samples with control sample. The relative change in the tanning content of treatments with the control is given in figure 2 .

Table 4 shows the catechin content $(\mathrm{mg} / 100$ $\mathrm{ml}$ ) of control and pretreated wine samples. Mean values of the catechin content $(\mathrm{mg} / 100$ $\mathrm{ml}$ ) in control and pretreated wine samples

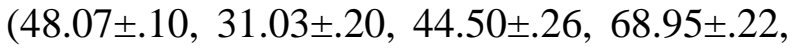
$30.07 \pm .22,30.75 \pm .12,33.33 \pm .20,36.20 \pm .70$, $35.15 \pm .18$ and $37.02 \pm .10)$ were obtained. It was found that there were significant $(\mathrm{P} \leq 0.01)$ changes in values of the catechin content of pretreated wine samples with control sample. The relative change in the catechin content of treatments with the control is given in figure 3.

\section{Effect of pretreatments on the quality of grape wine}

\section{Effect on total phenols}

The effect of microwave and conventional thermal pasteurization on the quality parameters of grape wine such as total phenols, tannin and catechin was studied. It was observed from table 2 that there was significant change in the total phenol content of grape must and wine among the treatments at 1 per cent level. The control recorded the total phenol contents of $452.28 \mathrm{mg} / 100 \mathrm{ml}$ of grape must and $175.12 \mathrm{mg} / 100 \mathrm{ml}$ for wine, respectively. The treatments exposed at $300 \mathrm{~W}$ power levels for 6 min expressed the mean total phenol content of $454.88 \mathrm{mg} / 100 \mathrm{ml}$ of 
grape must and $190.73 \mathrm{mg} / 100 \mathrm{ml}$ of wine. It was noticed that the microwave exposure for 6 min extracted the phenolic content higher than the control in the grape must and wine and also interpreted that the increase in microwave exposure increases the phenolic extraction in grape must and wine. The results observed were on par with the results of carew et al., (2014).

The intervention of conventional thermal pasteurization on the extraction of total phenol content from grapes was evaluated at 50, 60 and $70^{\circ} \mathrm{C}$ for 30 and $60 \mathrm{~s}$ exposure time. The thermal exposure of grape must at $50^{\circ} \mathrm{C}$ for 30 and $60 \mathrm{~s}$ showed a slight change in the total phenolic extraction and the treatments were on par $\left(T_{4}\right.$ and $\left.T_{5}\right)$ before fermentation whereas grape wine showed a significant difference at 1 per cent level of significance on the phenolic content. The increased exposure time improved the total phenolic extraction. The thermal exposure of grape must at $60^{\circ} \mathrm{C}$ for 30 and $60 \mathrm{~s}$ recorded $450.07 \mathrm{mg} / 100 \mathrm{ml}$ and $450.42 \mathrm{mg} / 100 \mathrm{ml}$, respectively whereas grape wine recorded $182.07 \mathrm{mg} / 100 \mathrm{ml}$ and 190.77 $\mathrm{mg} / 100 \mathrm{ml}$, respectively in the total phenolic content. The treatments were on par $\left(\mathrm{T}_{6}\right.$ and $\mathrm{T}_{7}$ ) before fermentation whereas grape wine showed a significant difference at 1 per cent level and the increased exposure time improved the total phenolic extraction.

The thermal exposure of grape must at $70^{\circ} \mathrm{C}$ for 30 and $60 \mathrm{~s}$ recorded $452.60 \mathrm{mg} / 100 \mathrm{ml}$ and $458.17 \mathrm{mg} / 100 \mathrm{ml}$, respectively whereas grape wine recorded $195.85 \mathrm{mg} / 100 \mathrm{ml}$ and $210.43 \mathrm{mg} / 100 \mathrm{ml}$, respectively in the total phenolic content and the treatments were on par $\left(\mathrm{T}_{8}\right.$ and $\left.\mathrm{T}_{9}\right)$ before fermentation whereas grape wine showed a significant difference at 1 per cent level of significance.

Among the treatments, higher total phenolic extraction was observed on the treatments that exposed to conventional thermal pasteurization than the treatments exposed to microwave. This may be because of the low power level of the microwave considered in this study. It was also observed that the total phenolic extraction due to the pretreatments was superior to control.

Fig.1 Flowchart for alcoholic fermentation of grape must

Pre-treated grape must

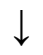

Adjust TSS $22^{\circ}$ Brix by adding cane sugar

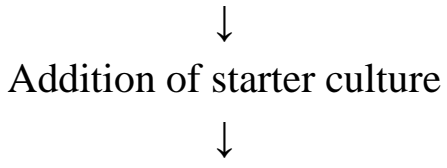

Fermentation at $28^{\circ} \mathrm{C}$ in $\mathrm{BOD}$ incubator under anaerobic condition for about 20 days

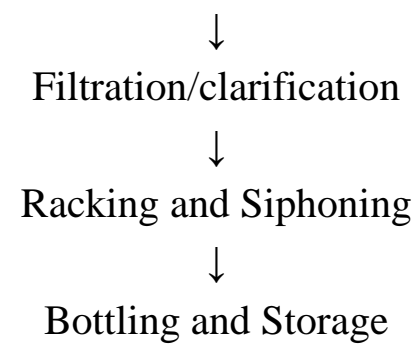


Fig.2 Comparison of tannin content $(\mathrm{mg} / 100 \mathrm{ml})$ of wine between control and treatments

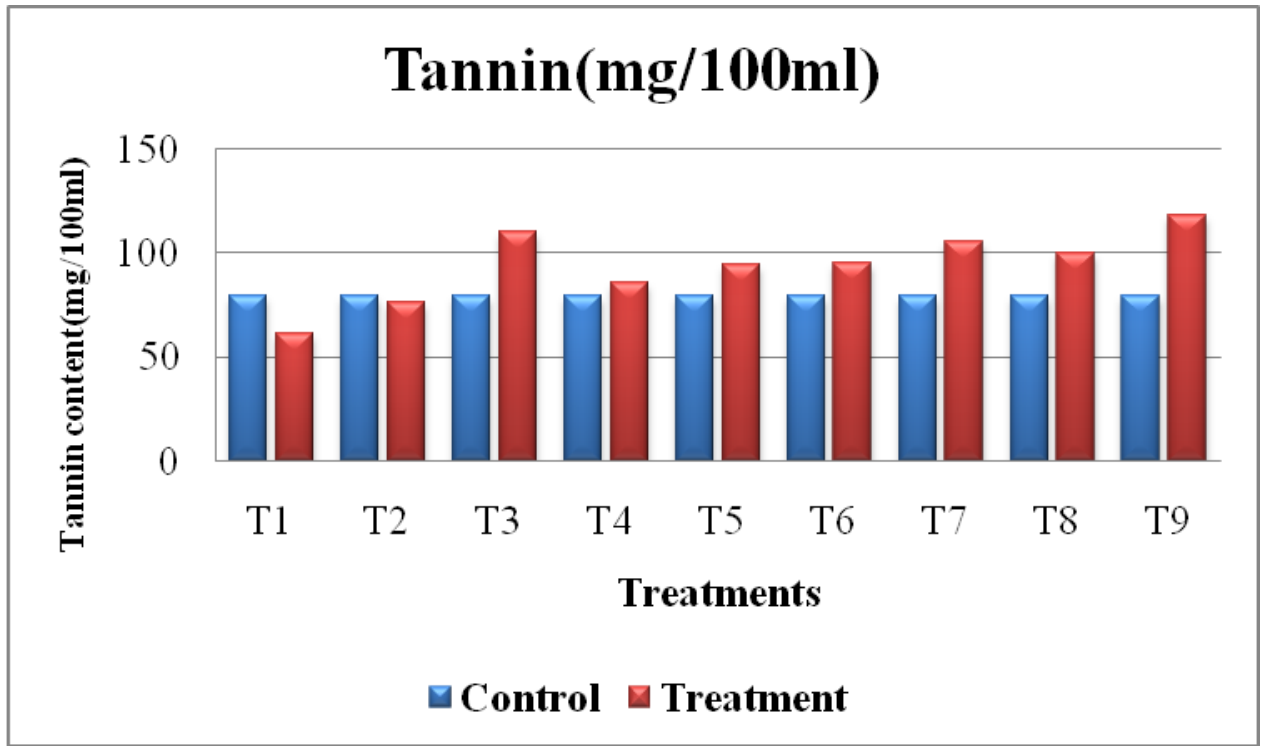

Fig.3 Comparison of catechin content $(\mathrm{mg} / 100 \mathrm{ml})$ of wine between control and treatments

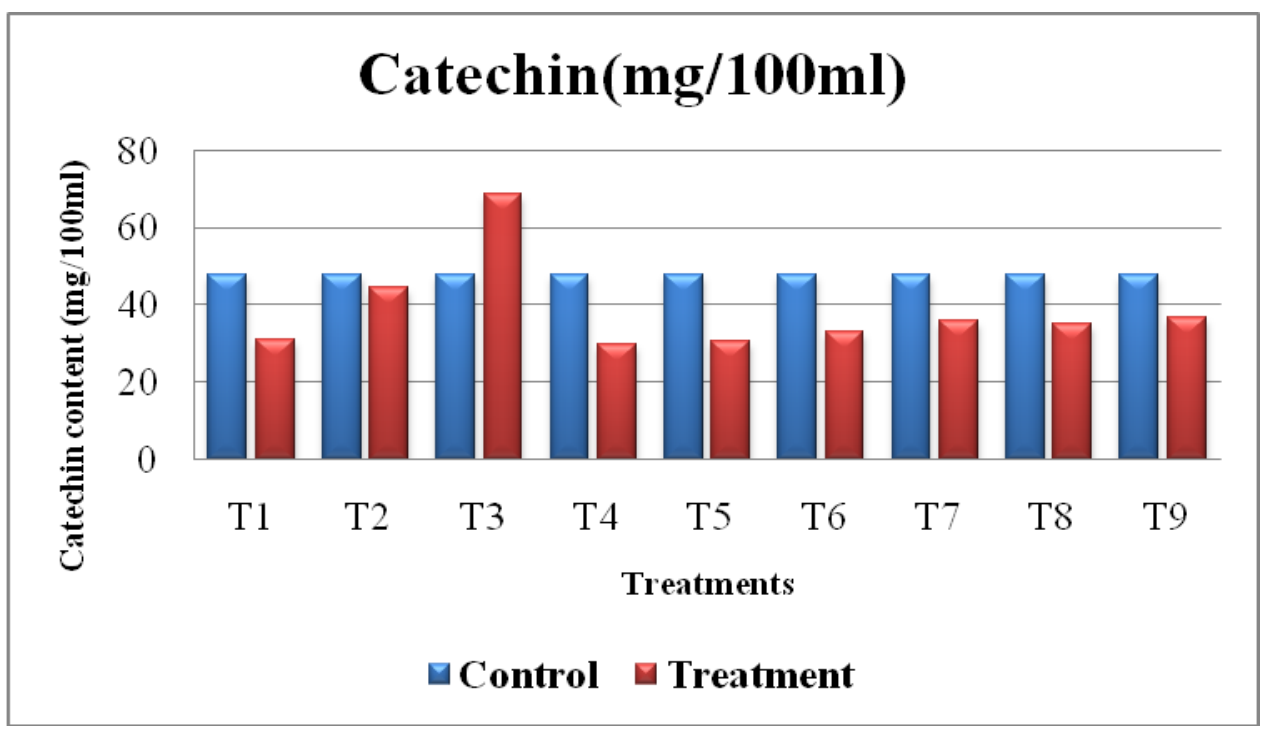

Table.1 Experimental design

\begin{tabular}{|c|c|c|c|}
\hline \multicolumn{3}{|c|}{ Dosages (Independent variables) } & Quality parameters (Dependent variables) \\
\hline \multirow{3}{*}{$\begin{array}{l}\text { Microwave } \\
\text { Treatment }\end{array}$} & \multirow[t]{3}{*}{$300 \mathrm{~W}$} & $2 \min \left(\mathrm{T}_{1}\right)$ & \multirow{6}{*}{$\begin{array}{l}\text { 1. } \quad \text { Total phenols } \\
\text { 2. } \quad \text { Tannins } \\
\text { 3. }\end{array}$} \\
\hline & & $4 \min \left(T_{2}\right)$ & \\
\hline & & $6 \min \left(T_{3}\right)$ & \\
\hline \multirow{3}{*}{ Pasteurization } & $50{ }^{\circ} \mathrm{C}$ & $30 \mathrm{~s}\left(\mathrm{~T}_{4}\right), 60 \mathrm{~s}\left(\mathrm{~T}_{5}\right)$ & \\
\hline & $60{ }^{\circ} \mathrm{C}$ & $30 \mathrm{~s}\left(\mathrm{~T}_{6}\right), 60 \mathrm{~s}\left(\mathrm{~T}_{7}\right)$ & \\
\hline & $70{ }^{\circ} \mathrm{C}$ & $30 \mathrm{~s}\left(\mathrm{~T}_{8}\right), 60 \mathrm{~s}\left(\mathrm{~T}_{9}\right)$ & \\
\hline
\end{tabular}


Table.2 Total phenol content of pretreated and control samples during wine fermentation $($ Mean \pm SE)

\begin{tabular}{|c|c|c|c|}
\hline Treatment & $\mathbf{0}^{\text {th }}$ day & $\mathbf{2 0}^{\text {th }}$ day & F-Value \\
\hline Control & $452.28 \pm 0.26^{\mathrm{d}}$ & $175.12 \pm 0.12^{\mathrm{a}}$ & $955710.014^{* *}$ \\
\hline $\mathbf{T}_{\mathbf{1}}$ & $445.58 \pm 0.25^{\mathrm{a}}$ & $176.62 \pm 0.17^{\mathrm{d}}$ & $771444.569^{* *}$ \\
\hline $\mathbf{T}_{\mathbf{2}}$ & $449.27 \pm 0.35^{\mathrm{b}}$ & $178.98 \pm 0.12^{\mathrm{c}}$ & $558303.391^{* *}$ \\
\hline $\mathbf{T}_{\mathbf{3}}$ & $454.88 \pm 0.28^{\mathrm{e}}$ & $190.73 \pm 0.22^{\mathrm{f}}$ & $599834.362^{* *}$ \\
\hline $\mathbf{T}_{\mathbf{4}}$ & $445.23 \pm 0.2^{\mathrm{a}}$ & $176.35 \pm 0.19^{\mathrm{b}}$ & $749070.011^{* *}$ \\
\hline $\mathbf{T}_{\mathbf{5}}$ & $446.03 \pm 0.26^{\mathrm{a}}$ & $178.40 \pm 0.17^{\mathrm{d}}$ & $984846.176^{* *}$ \\
\hline $\mathbf{T}_{\mathbf{6}}$ & $450.07 \pm 0.23^{\mathrm{c}}$ & $182.07 \pm 0.22^{\mathrm{d}}$ & $473784.817^{*} *$ \\
\hline $\mathbf{T}_{\mathbf{7}}$ & $450.42 \pm 0.27^{\mathrm{c}}$ & $190.77 \pm 0.3^{\mathrm{e}}$ & $764747.191^{*} *$ \\
\hline $\mathbf{T}_{\mathbf{8}}$ & $452.60 \pm 0.34^{\mathrm{d}}$ & $195.85 \pm 0.3^{\mathrm{g}}$ & $371291.804^{*} *$ \\
\hline $\mathbf{T}_{\mathbf{9}}$ & $458.17 \pm 0.22^{\mathrm{f}}$ & $210.43 \pm 0.3^{\mathrm{h}}$ & $604723.206^{* *}$ \\
\hline F-Value & $241.999^{*} *$ & $264.751^{* *}$ & \\
\hline
\end{tabular}

**- Highly significant $(\mathrm{P} \leq 0.01)$ at intervals, ${ }^{\text {a, }}, \mathrm{c}$ and $\mathrm{ABCDE}$ - superscripts with same letter indicates the treatments are on par

Table.3 Tannin content $(\mathrm{mg} / 100 \mathrm{ml})$ of wine $($ Mean $\pm \mathrm{SE})$

\begin{tabular}{|c|c|}
\hline Treatment & Wine \\
\hline Control & $79.88 \pm .09^{\mathrm{b}}$ \\
\hline $\mathbf{T}_{\mathbf{1}}$ & $61.50 \pm .35^{\mathrm{a}}$ \\
\hline $\mathbf{T}_{\mathbf{2}}$ & $76.20 \pm .22^{\mathrm{e}}$ \\
\hline $\mathbf{T}_{\mathbf{3}}$ & $109.98 \pm .19^{\mathrm{h}}$ \\
\hline $\mathbf{T}_{\mathbf{4}}$ & $86.18 \pm .26^{\mathrm{c}}$ \\
\hline $\mathbf{T}_{\mathbf{5}}$ & $94.83 \pm .12^{\mathrm{d}}$ \\
\hline $\mathbf{T}_{\mathbf{6}}$ & $95.05 \pm .23^{\mathrm{d}}$ \\
\hline $\mathbf{T}_{\mathbf{7}}$ & $105.70 \pm .12^{\mathrm{g}}$ \\
\hline $\mathbf{T}_{\mathbf{8}}$ & $100.20 \pm .12^{\mathrm{f}}$ \\
\hline $\mathbf{T}_{\mathbf{9}}$ & $118.27 \pm .17^{\mathrm{i}}$ \\
\hline F-Value & $6317.294^{* *}$ \\
\hline
\end{tabular}

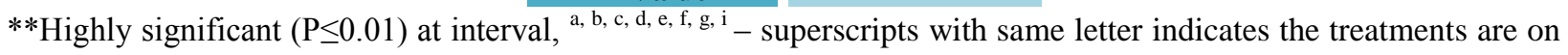
par.

Table.4 Catechin content $(\mathrm{mg} / 100 \mathrm{ml})$ of wine (Mean $\pm \mathrm{SE})$

\begin{tabular}{|c|c|}
\hline Treatment & Wine \\
\hline Control & $48.07 \pm .10^{\mathrm{h}}$ \\
\hline $\mathbf{T}_{\mathbf{1}}$ & $31.03 \pm .20^{\mathrm{b}}$ \\
\hline $\mathbf{T}_{\mathbf{2}}$ & $44.50 \pm .26^{\mathrm{g}}$ \\
\hline $\mathbf{T}_{\mathbf{3}}$ & $68.95 \pm .22^{\mathrm{i}}$ \\
\hline $\mathbf{T}_{\mathbf{4}}$ & $30.07 \pm .22^{\mathrm{a}}$ \\
\hline $\mathbf{T}_{\mathbf{5}}$ & $30.75 \pm .12^{\mathrm{ab}}$ \\
\hline $\mathbf{T}_{\mathbf{6}}$ & $33.33 \pm .20^{\mathrm{c}}$ \\
\hline $\mathbf{T}_{\mathbf{7}}$ & $36.20 \pm .70^{\mathrm{c}}$ \\
\hline $\mathbf{T}_{\mathbf{8}}$ & $35.15 \pm .18^{\mathrm{d}}$ \\
\hline $\mathbf{T}_{\mathbf{9}}$ & $37.02 \pm .10^{\mathrm{f}}$ \\
\hline F-Value & $1769.973^{* *}$ \\
\hline
\end{tabular}

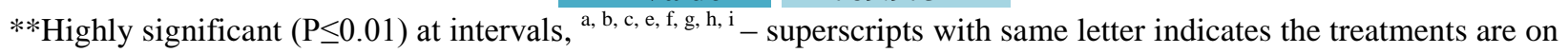
par 


\section{Plate.1 Conventional thermal pasteurization treatment}
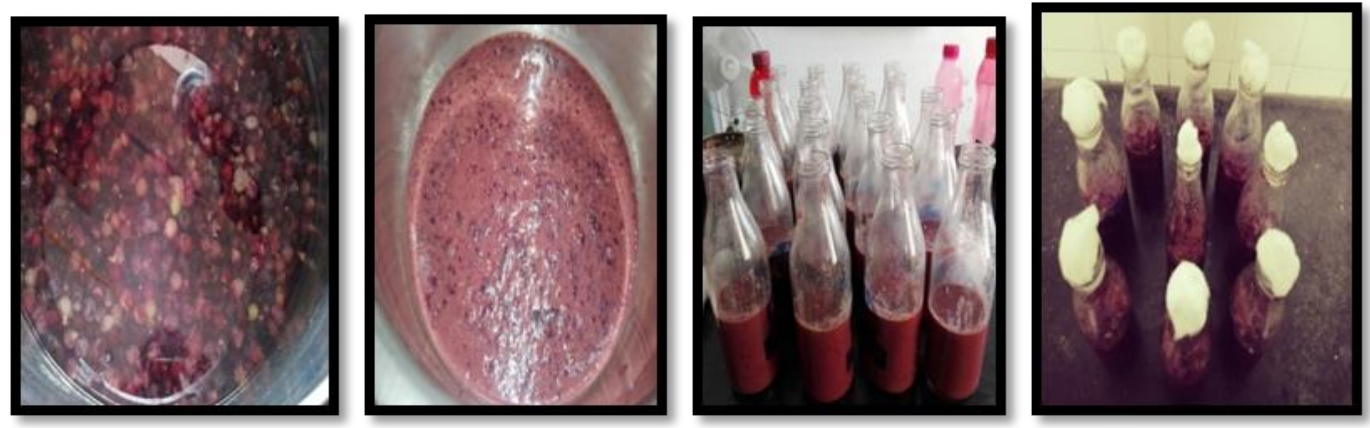

Plate.2 Microwave treatment
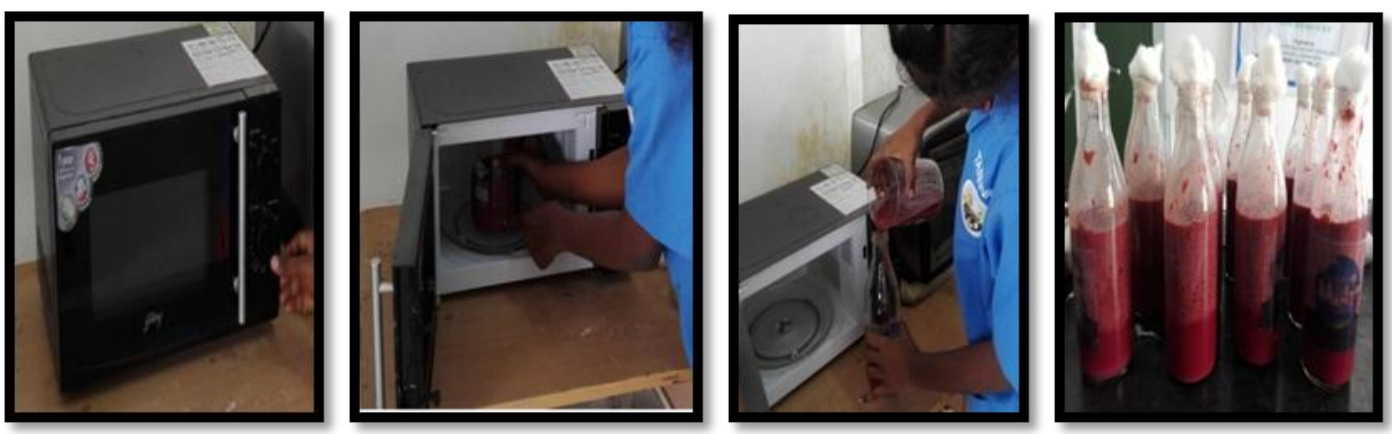

Plate.3 Wine making
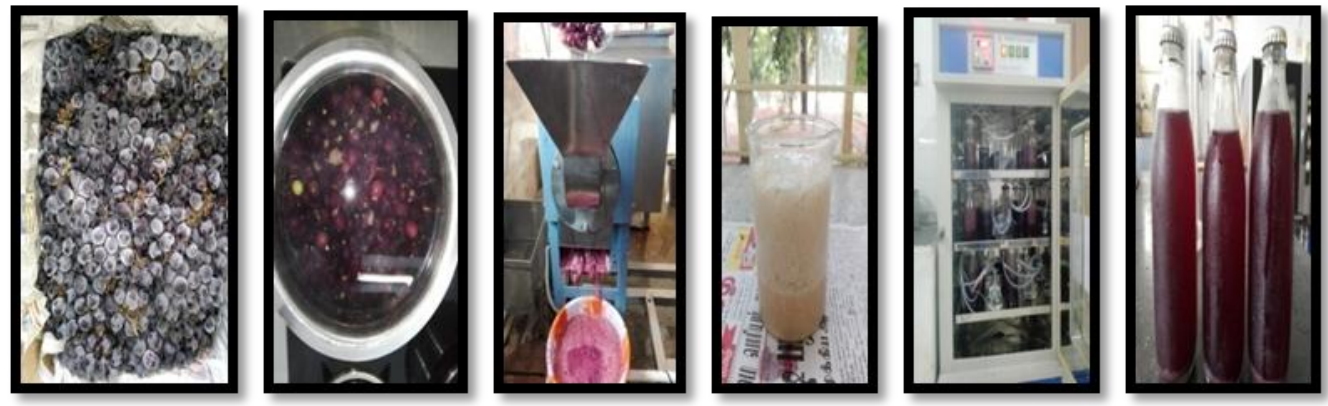

a) Grapes, b) Blanching, c) grape must, d) Brewer's Yeast, e) BOD incubator, f) wine

\section{Effect on tannins}

It was observed from table 4.9 that there was significant change in the tannin content of grape wine among the treatments at 1 per cent level. The control recorded the tannin contents of $79.88 \mathrm{mg} / 100 \mathrm{ml}$ of grape wine. The treatments exposed at $300 \mathrm{~W}$ power levels for $6 \mathrm{~min}$ expressed the mean tannin content of $109.98 \mathrm{mg} / 100 \mathrm{ml}$ of grape wine. It was noticed that the microwave exposure for 6 min extracted the tannin content higher than the control in the grape wine. It was also interpreted that the increase in microwave exposure increases the tannin extraction in grape wine.

The intervention of conventional thermal pasteurization on the extraction of tannin content from grape wine were evaluated at 50, 
60 and $70^{\circ} \mathrm{C}$ for 30 and 60 s exposure time. The thermal exposure of grape must at $50^{\circ} \mathrm{C}$ for 30 and $60 \mathrm{~s}$ showed a slight change in the tannin extraction and the treatments $\left(\mathrm{T}_{6}\right.$ and $\mathrm{T}_{7}$ ) showed a significant difference. The increased exposure time improved the tannin extraction. The thermal exposure of $60^{\circ} \mathrm{C}$ for 30 and $60 \mathrm{~s}$ recorded $95.05 \mathrm{mg} / 100 \mathrm{ml}$ and $105.70 \mathrm{mg} / 100 \mathrm{ml}$ of grape wine, respectively and the treatments $\left(\mathrm{T}_{6}\right.$ and $\left.\mathrm{T}_{7}\right)$ showed a significant difference. The thermal exposure of $70^{\circ} \mathrm{C}$ for 30 and $60 \mathrm{~s}$ recorded 100.20 $\mathrm{mg} / 100 \mathrm{ml}$ and $118.27 \mathrm{mg} / 100 \mathrm{ml}$ of grape wine, respectively in the tannin extraction.

Among the treatments, higher tannin extraction was observed on the treatments that exposed to conventional thermal pasteurization than the treatments exposed to microwave. This may be because of the low power level of the microwave considered in this study. It was also found that increased exposure time and dosage level improved the tannin extraction. It was also observed that the tannin extraction due to the pretreatments was superior to control.

\section{Effect on catechins}

It was observed from table 4.10 that there was significant change in the catechin content of grape wine among the treatments at 1 per cent level. The control recorded the catechin contents of $48.07 \mathrm{mg} / 100 \mathrm{~L}$ of grape wine. The treatments exposed at $300 \mathrm{~W}$ power level for 6 min expressed the mean catechin content of $68.95 \mathrm{mg} / 100 \mathrm{ml}$ of grape wine whereas treatments exposed at $300 \mathrm{~W}$ power level for 2 min and 4 min expressed the mean catechin content of grape wine $31.03 \mathrm{mg} / 100 \mathrm{ml}$ and $44.50 \mathrm{mg} / 100 \mathrm{ml}$ of grape wine, respectively. It was noticed that the microwave exposure for 6 min extracted the catechin content higher than the control in the grape wine. It was found that the microwave exposure for 2 and 4 min decreased the catechin content than the control in the grape wine. The increased exposure time of microwave improved the catechin content in wine.

The intervention of conventional thermal pasteurization on the extraction of catechin content from grape wine were evaluated at 50, 60 and $70^{\circ} \mathrm{C}$ for 30 and 60 s exposure time.

The thermal exposure of $50^{\circ} \mathrm{C}$ for 30 and $60 \mathrm{~s}$ showed a slight change in the catechin extraction and the treatments $\left(\mathrm{T}_{4}\right.$ and $\left.\mathrm{T}_{5}\right)$ were on par. The increased exposure time decreased the catechin extraction than the control. The thermal exposure of $60^{\circ} \mathrm{C}$ for 30 and $60 \mathrm{~s}$ recorded $33.33 \mathrm{mg} / 100 \mathrm{ml}$ and 36.20 $\mathrm{mg} / 100 \mathrm{ml}$ of grape wine, respectively and the treatments were on par $\left(\mathrm{T}_{6}\right.$ and $\left.\mathrm{T}_{7}\right)$. The increased exposure time improved the catechin extraction.

The thermal exposure of $70^{\circ} \mathrm{C}$ for 30 and $60 \mathrm{~s}$ recorded $35.15 \mathrm{mg} / 100 \mathrm{ml}$ and $37.02 \mathrm{mg} / 100$ $\mathrm{ml}$ of grape wine, respectively in the catechin extraction and the treatments $\left(\mathrm{T}_{8}\right.$ and $\left.\mathrm{T}_{9}\right)$ showed a significant difference. Among the pretreatments, microwave treated samples exposed for $6 \mathrm{~min}$ exhibited higher catechin extraction whereas among the conventional pasteurization treatments $70^{\circ} \mathrm{C}$ for $60 \mathrm{~s}$ showed maximum extraction than the others. It was also observed that the catechin extraction due to the microwave pretreatments was superior to control and conventional thermal pasteurization. The results were confirmed by Clodoveo et al., (2016).

While considering the quality parameters of wine such as total phenol content, tannin and catechins, the conventional thermal pasteurization recorded maximum values for the total phenols and tannins than the control and microwave samples whereas catechin was found higher in microwave samples than the control and samples exposed to thermal pasteurization. 


\section{Acknowledgement}

The authors acknowledge the help provided by the Department of Food Plant Operations, College of Food and Dairy Technology and Department of Dairy Science, Madras Veterinary College and TRPVB, Madhavaram, TANUVAS for utilizing the lab facilities for red wine production and analysis.

\section{References}

Carew, A. L., W. Gill, D. C. Close and R. G. Dambergs, 2014. Microwave maceration with early press off improves phenolics and fermentation kinetics in Pinot Noir. American Journal of Enology and Viticulture, ajev-2014.

Casas, L., Mantell, C., Rodriguez, M., Martinez, D.L.O., Roldan, E.J., De ory, I., et al., 2010.Extraction of resveratrol from the pomace of Palomino fino grapes by supercritical carbon dioxide. Journal of Food Engineering 96: 304308.

Charoenchai, C., G. H. Fleet and P. A. Henschke, 1998.Effects of temperature, $\mathrm{pH}$, and sugar concentration on the growth rates and cell biomass of wine yeasts. American Journal of Enology and Viticulture, 49(3): 283-288.

Clodoveo, M. L., T. Dipalmo, C. G. Rizzello, F. Corbo and P. Crupi, (2016). Emerging technology to develop novel red winemaking practices: An overview. Innovative Food Science \& Emerging Technologies, 38: 41-56.

Liu, J. L., J. F. Yuanand and Z. Q. Zhang, 2010. Microwave- assisted extraction optimised with response surface methodology and antioxidant activity of polyphenols from hawthorn (Crataegus pinnatifida Bge.) fruit. International journal of food science and technology, 45(11): 2400-2406.

Pederson, C. S., E. A. Beavens and H. E. Goresline, (1936). Preservation of Grape Juice. Iv. Pasteurization Of Juices Or Musts Prepared From Several Varieties of Grapes 1- 2. Journal of Food Science, 1(4): 325-335.

Torija, M. J., N. Rozes, M. Poblet, J. M. Guillamón and A. Mas, 2003. Effects of fermentation temperature on the strain population of Saccharomyces cerevisiae. International journal of food microbiology, 80(1): 47-53.

\section{How to cite this article:}

Navarasam, R., N. Karpoora Sundara Pandian, B. Dhanalakshmi and Abdul Reiyas, M. 2018. Effect of Pretreatments on the Quality of Grape Wine. Int.J.Curr.Microbiol.App.Sci. 7(10): 183-192. doi: https://doi.org/10.20546/ijcmas.2018.710.019 